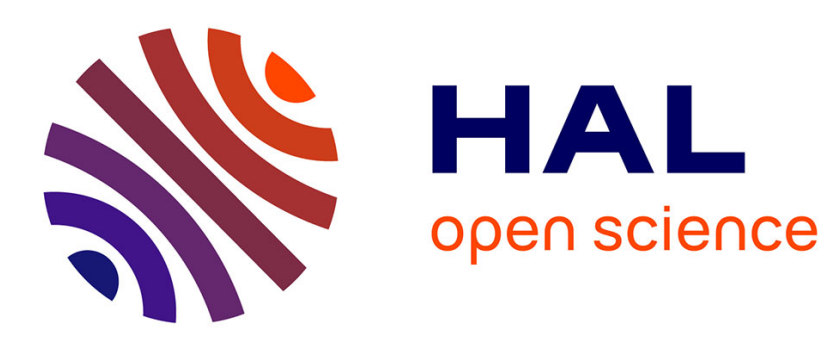

\title{
Targeted approaches and innovative illumination solutions: A new era for photodynamic therapy applications in gynecologic oncology?
}

\author{
Henri Azais, Nacim Betrouni, Serge Mordon, Pierre Collinet
}

\section{- To cite this version:}

Henri Azais, Nacim Betrouni, Serge Mordon, Pierre Collinet. Targeted approaches and innovative illumination solutions: A new era for photodynamic therapy applications in gynecologic oncology? . 2015. hal-01183327

\author{
HAL Id: hal-01183327 \\ https://hal.science/hal-01183327
}

Submitted on 31 Aug 2015

HAL is a multi-disciplinary open access archive for the deposit and dissemination of scientific research documents, whether they are published or not. The documents may come from teaching and research institutions in France or abroad, or from public or private research centers.
L'archive ouverte pluridisciplinaire HAL, est destinée au dépôt et à la diffusion de documents scientifiques de niveau recherche, publiés ou non, émanant des établissements d'enseignement et de recherche français ou étrangers, des laboratoires publics ou privés. 
1

3

4

5

6

7

8 10

14

15

16

17

18

19

20

21

22

23

24

25

26

27

28

29

30

31

32

33

6

9

0

\section{Editorial}

Targeted approaches and innovative illumination solutions:

A new era for photodynamic therapy applications in gynecologic oncology ? 10

(1)

AZAïS Henri ${ }^{1,2}$, BETROUNINacim ${ }^{1}$, MORDON Serge ${ }^{1}$, COLLINET Pierre ${ }^{1,2}$.

4

5

7 1- INSERMU1189 - ONCO-THAI, University of Lille, 59000 Lille, France.

8 2- Department of Gynecology, University of Lille, 59000 Lille, France

(1)

Corresponding Author

Henri AZAïs

5 INSERMU1189 - ONCO-THAI

6 University of Lille

1 1, avenue Oscar Lambret

2859037 Lille - France

9 henriazais@gmail.com 


\section{HIGHLIGHTS}

- PDT could be part of innovative management of gynecological cancer.

- Targeted photosensitizers may improve therapeutic index of intraperitoneal PDT.

\section{EDITORIAL}

Different studies have been carried out to investigatethe potential application of photodiagnosisand photodynamic therapy (PDT) in the field of gynecological cancer treatment without finding a place in current standard clinical practice.

Photodiagnosis isbased on the principlethatabnormal tissues absorb light and fluoresce differentlyfrom normal tissues atspecificlight wavelengths. Autofluorescence takesadvantageof thisprinciple. Fluorescence canbeenhanced by the use of exogenous markers (photosensitizers) ${ }^{[1]}$. This technique, which has been evaluated in preclinical and clinical studies, has shown a good accuracy to detect peritoneal metastasis of ovarian origin, increasing the number of lesion detected by more than a third, and allowing easier detection of submillimericlesions. As a feasible application, photodiagnosis could be an efficientdecision-support technology to help the surgeon to take a decision during explorative laparoscopy before cytoreductive surgery for peritoneal carcinomatosis in ovarian cancer. Nevertheless, the therapeutic impact of fluorescence guided surgery remains uncertain as it is not possible to treat the entire peritoneal cavity surgically, even if more lesions are removed, and photodiagnosis will always be limited by optical detection device performances. High peritoneal recurrence rate after optimal treatment of advanced ovarian cancer by the association of platinum-based chemotherapy and complete cytoreductive surgery raises the issue of peritoneal microscopic disease management and requires the development of additionallocoregional treatment 60 strategies.

61 Photodynamic therapy is an efficient treatment already applied in other medical indications such as dermatology, thoracic surgery or urology. After administration of a photosensitizer (PS) which 
63 accumulates in cancer cells, its illumination with a light of adequate wavelength may induce 64 photochemical reaction with tissue oxygen which lead to reactive oxygen species production and 65 cytotoxic phenomenon. Its ability to treat superficial lesions disseminated on large area makes it an excellent candidate to insure destruction of microscopic residual disease in complement of surgery and in addition of chemotherapy, even in prophylactic intent on apparently normal peritoneum, in early-stage ovarian cancer.

Development of intraperitoneal PDT has been confronted with a poor tolerance related to the lack of specificity of photosensitizers and the proximity of intraperitoneal organ. First generation photosensitizer porfimersodium is the only PS which has been clinically evaluated in intraperitoneal indication in phases I and II trials ${ }^{[2-4]}$. In these studies, the authors rapport high grade morbidity as digestive perforation, capillary leaks syndrome and no benefit has been observed neither on progression-free survival nor on global survival. This narrow therapeutic window ${ }^{[3]}$ has been attributed to a narrow differential in drug selectivity betweentumor and normal tissues of the peritoneal cavity ${ }^{[5]}$.As stated by Cengel et al., molecularly targeted photosensitizers have a strong clinical potential and are needed to improve therapeutic index of intraperitoneal PDT ${ }^{[6]}$.

In this issue of Photodiagnosis and Photodynamic Therapy, we present our result regarding the preclinical evaluation of a new generation targeted photosensitizer and its specificity for ovarian peritoneal metastasis. We have used FRa which is a pertinent target to develop targeted therapy in gynecologic malignancies as stated by numerous recent publications which describe the high specificity of this receptor for tumour, its expression stability between primitive cancer and peritoneal metastasis, in case of recurrences, and after chemotherapy ${ }^{[7-12]}$,

Other applications could be clinically relevant in gynecological cancer. In early stage endometrial cancer, it seems possible to propose conservative treatment with targeted PDT for young women who are eligible for fertility sparing treatment ${ }^{[13]}$. Folate targeted PDT could be developed in this indication as some serous endometrial cancer overexpress $\mathrm{FRa}^{[9,10]}$. Intracavitarian illumination of endometrial cancer would be much easier than intraperitoneal illumination without the risk of visceral injuries and could so be repeated if needed to enhance its efficacy. In early stage cervical cancer or cervical intra- 
epithelial neoplasia, PDT could also be an effective fertility sparing treatment option in addition with conisation $^{[14]}$.

Another aspect of photodynamic therapy development is the illumination using an optimal scheme and a light administration monitoring. Innovative illumination solutions are available, as textile light diffusers which offer the possibility to apply a homogenous distribution of light on large surface area, as parietal peritoneum ${ }^{[15]}$ or direct and cylindrical diffusing fibreswhich are easy to handle and allow reaching spaces that are difficult to attain. Homogeneity of light distribution inside the peritoneal cavity can be improved by filling it with a dilute intralipid solution which acts as an optical diffusing medium ${ }^{[16,17]}$. Oxygen depletion is the major reason of relative treatment failure. Besides fractionation of light, numerous studies have clearly demonstrated that PDT efficacy can be enhanced by instillation of hyperoxygenated fluids during light irradiation ${ }^{[18]}$. The fluence rate and the wavelength must be adapted to exposed organs to limit light penetration and to reduce the risk of deep visceral injuries. Light emission monitoring and source tracking are feasible to ensure a complete and homogenous illumination of any anatomical cavity as it is already performed for pleural mesothelioma treatment with promising results ${ }^{[19]}$. Moreover, the combination of this spatial tracking and imaging modalities allows a real-time feedback and display of the applied dose.

In conclusion, intraperitoneal photodynamic therapy requires having an expert knowledge of several parameters. It is essential to propose to the clinicians a device which allows a reproducible and efficient illumination procedure. With targeted photosensitizers and recent illumination innovations, photodynamic therapy could be part of innovative management in gynecological cancer care.

\section{CONFLICT OF INTEREST STATEMENT}

119 The authors declare that there have no conflicts of interest. 


\section{REFERENCES}

1. Guyon L, Ascencio M, Collinet $P$, Mordon S. Photodiagnosis and photodynamic therapy of peritoneal metastasis of ovarian cancer. Photodiagnosis Photodyn Ther 2012;9(1):16-31.

2. Delaney TF, Sindelar WF, Tochner Z, Smith PD, Friauf WS, Thomas G, et al. Phase I study of debulking surgery and photodynamic therapy for disseminated intraperitoneal tumors. Int $\mathrm{J}$ Radiat Oncol 1993;25(3):445-57.

3. Hahn SM, Fraker DL, Mick R, Metz J, Busch TM, Smith D, et al. A Phase II Trial of Intraperitoneal Photodynamic Therapy for Patients with Peritoneal Carcinomatosis and Sarcomatosis. Clin Cancer Res 2006;12(8):2517-25.

4. Hendren SK, Hahn SM, Spitz FR, Bauer TW, Rubin SC, Zhu T, et al. Phase II trial of debulking surgery and photodynamic therapy for disseminated intraperitoneal tumors. Ann Surg Oncol 2001;8(1):65-71.

5. Hahn SM, Putt ME, Metz J, Shin DB, Rickter E, Menon C, et al. Photofrin uptake in the tumor and normal tissues of patients receiving intraperitoneal photodynamic therapy. Clin Cancer Res Off $J$ Am Assoc Cancer Res 2006;12(18):5464-70.

6. Cengel KA, Glatstein E, Hahn SM. Intraperitoneal photodynamic therapy. Cancer Treat Res 2007;134:493-514.

7. Kalli $K R$, Oberg AL, Keeney GL, Christianson $T J H$, Low PS, Knutson KL, et al. Folate receptor alpha as a tumor target in epithelial ovarian cancer. Gynecol Oncol 2008;108(3):619-26.

8. Crane LMA, Arts HJG, Oosten M, Low PS, Zee AGJ, Dam GM, et al. The effect of chemotherapy on expression of folate receptor-alpha in ovarian cancer. Cell Oncol 2011;35(1):9-18.

9. Despierre E, Lambrechts $S$, Leunen $K$, Berteloot $P$, Neven $P$, Amant $F$, et al. Folate receptor alpha (FRA) expression remains unchanged in epithelial ovarian and endometrial cancer after chemotherapy. Gynecol Oncol 2013;130(1):192-9.

10. O'Shannessy DJ, Somers EB, Smale R, Fu Y-S. Expression of folate receptor-a (FRA) in gynecologic malignancies and its relationship to the tumor type. Int J Gynecol Pathol Off J Int Soc Gynecol Pathol 2013;32(3):258-68.

11. Markert S, Lassmann S, Gabriel B, Klar M, Werner M, Gitsch G, et al. Alpha-folate Receptor Expression in Epithelial Ovarian Carcinoma and Non-neoplastic Ovarian Tissue. Anticancer Res 2008;28(6A):3567-72.

12. Walters $\mathrm{CL}$, Arend RC, Armstrong DK, Naumann RW, Alvarez RD. Folate and folate receptor alpha antagonists mechanism of action in ovarian cancer. Gynecol Oncol 2013; 
13. Choi MC, Jung SG, Park $H$, Cho YH, Lee C, Kim SJ. Fertility preservation via photodynamic therapy in young patients with early-stage uterine endometrial cancer: a long-term follow-up study. Int J Gynecol Cancer Off J Int Gynecol Cancer Soc 2013;23(4):698-704.

14. Choi MC, Jung SG, Park $H$, Lee SY, Lee $C$, Hwang $Y Y$, et al. Fertility preservation by photodynamic therapy combined with conization in young patients with early stage cervical cancer: A pilot study. Photodiagnosis Photodyn Ther [Internet] [cited 2014 Jul 7];Available from: http://www.sciencedirect.com/science/article/pii/S1572100014000866

15. Cochrane C, Mordon SR, Lesage JC, Koncar V. New design of textile light diffusers for photodynamic therapy. Mater Sci Eng C 2013;33(3):1170-5.

16. Perry RR, Evans S, Matthews W, Rizzoni W, Russo A, Pass HI. Potentiation of phototherapy cytotoxicity with light scattering media. J Surg Res 1989;46(4):386-90.

17. Friedberg JS. Photodynamic therapy as an innovative treatment for malignant pleural mesothelioma. Semin Thorac Cardiovasc Surg 2009;21(2):177-87.

18. Huygens A, Kamuhabwa AR, Van Laethem A, Roskams T, Van Cleynenbreugel B, Van Poppel H, et al. Enhancing the photodynamic effect of hypericin in tumour spheroids by fractionated light delivery in combination with hyperoxygenation. Int J Oncol 2005;26(6):1691-7.

19. Friedberg JS, Mick R, Culligan M, Stevenson J, Fernandes A, Smith $D$, et al. Photodynamic therapy and the evolution of a lung-sparing surgical treatment for mesothelioma. Ann Thorac Surg 2011;91(6):1738-45. 